\title{
プラズマアクチュエータによる後向きステップ流れの損失低減*
}

\author{
佐野正利 ${ }^{* 1}$, 須藤輝美 ${ }^{* 2}$, 遠藤慶亮 ${ }^{* 3}$, 杉山勇気 $^{* 3}$, 鈴木 進 $^{* 4}$
}

\section{Reduction of Pressure Loss in Backward-Facing Step Flow with Plasma Actuator}

\author{
Masatoshi SANO*1 ${ }^{*}$ Terumi SUDO, Kyosuke ENDO, \\ Yuki SUGIYAMA and Susumu SUZUKI \\ ${ }^{*}$ Chiba Institute of Technology, Department of Mechanical Science and Engineering \\ 2-17-1 Tsudanuma, Narashino-shi, Chiba, 275-0016 Japan
}

An experimental study is performed for channel flow over a backward-facing step with the dielectric barrier discharge plasma actuator (DBD-PA). The plasma actuator consists of two metallic electrodes mounted on both sides of a dielectric plate. The actuator is installed on the corner edge of the step. The Reynolds number based on the mean velocity at the inlet and the step height ranges from 860 to 3240. The wall static pressure is measured, and the pressure loss coefficient is evaluated. The velocity profiles and turbulent intensities are measured by a PIV system at the Reynolds number of 1080, 1520 and 2170. The results show that the pressure drop at the step decreases by the effect of induced flow with the plasma actuator and the reattachment length is shorter compared with that of the steady flow condition. When the wave form with voltage of $6 \mathrm{kV}$ and frequency of $2 \mathrm{kHz}$ is applied to the electrode, the maximum pressure loss reduction rate of $31 \%$ is confirmed in the laminar flow region.

Key Words : Channel Flow, Plasma Actuator, Backward-Facing Step, Pressure Drop, Loss Reduction, PIV

\section{1. 緒言}

流体機器や熱交換機などの内部流れでは，はく離と再付着が現れることが多い. はく離の発生は圧力損失の増 大や振動・騒音の発生要因となることからその制御が望まれる. はく離・再付着を伴う流れの代表的な例として 後向きステップ流れがある，後向きステップ流れは，流路の形状は単純ではあるが，はく離，再循環，再付着な どの様々な形態の流れが共存寸るため流れ場の解明とともに，かかる流れ場を制御するためにこれまで多くの研 究がなされている．例えば，能動的制御としてステップ角部後方に設けたスピーカからの擾乱 ${ }^{(1)}$, 周期的な吹出 し・吸込み(2)，ステップ下端からの吸込み() などの方法が提案されている.さらに，機器の小型化に伴い低レイ， ルズ数領域の流れに対して Synthetic jet を適用した場合の結果についても報告されている(4). 受動的制御の例とし ては，ステップ近傍に円柱を挿入する(5)，ステップと対向する面にスラットを設置する(6)， ステップに傾斜を設 ける(7)などの方法が提案されている.

近年，流体制御用のデバイスとして誘電体バリア放電による大気圧非平衡プラズマを用いたプラズマアクチュ エータ（DBD-PA）が注目を集めている(8)(9).このアクチュエータを用いることにより，壁面近傍に流れを誘起で きる ${ }^{(10)}$.また，このアクチュエータの特徵として，構造が簡単，小型化が容易，機械的駆動部を持たない，など

\footnotetext{
* 原稿受付 2011 年 11 月 18 日

*1 正員, 千葉工業大学工学部（干275-0016 千葉県習志野市津田沼 2-17-1）

*2 正員, 高砂熱学工業(株)（广101-8321 東京都千代田区神田駿河台 4-2-5)

*3 学生員, 千葉工業大学大学院工学研究科

*4 千葉工業大学工学部

E-mail: sano.masatoshi@it-chiba.ac.jp
} 
があげられる. 小方ら ${ }^{(11)}$ は印加電圧の特性がプラズマアクチュエータの誘起流方向に与える影響を明らかにし， 山田ら ${ }^{(12)}$ は円柱表面にプラズマアクチュエータを取り付け，主流に対して順方向と逆方向のジェットを用いた場 合の円柱から放出される渦の挙動について検討している. 長谷部ら ${ }^{(13)}$ はプラズマアクチュエータを設置した翼周 りの流れを数值シミュレーションと風洞実験とから調査し，その効果を検証している．樋口ら ${ }^{(14)}$ は壁面せん断応 力センサを用い，乱流境界層内の壁面せん断応力に及ぼ寸影響について報告している．松田ら ${ }^{(15)}$ は，主流速度が 30〜 $50 \mathrm{~m} / \mathrm{s}$ と比較的速い流速のもとで後向きステップ流れにプラズマアクチュエータを使用し，このアクチュエ 一タが高レイノルズ数領域においても再付着長さの短縮に有効となることを示している. しかしながら，松田ら の研究では圧力損失の低減効果については報告されていない.

本論文では，最初に実験で使用するプラズマアクチュエータの誘起流特性や消費電力の測定結果について述心゙ る.ついで，このアクチュエータを後向きステップのあるチャネル流れに適用し，拡大部で発生する圧力損失の 低減効果を調査した結果について報告する. また, 代表的なレイノルズ数については, 粒子画像流速測定法 (PIV) を用いて速度場を測定し，アクチュエータの駆動による流れ場の変化と損失低減との関係について検討する.

\section{2. 実験装置および方法}

本実験で使用するプラズマアクチュエータの構造を図 1 に示す。このアクチュエータは，互いに位置をずらし た電極で誘電体を挟むという非常に簡単な構造をしている．この電極間に高電圧を印加することにより誘電体バ リア放電が生じ, 高電圧電極から接地電極へ外力が生じて流れが誘起される. Roth $ら^{(16)}$ は, 誘起速度が電極幅や

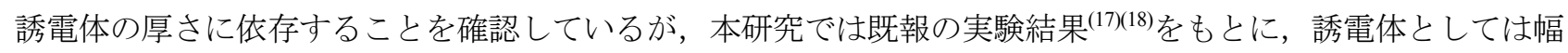
$250 \mathrm{~mm}$, 長さ $20 \mathrm{~mm}$, 厚さ $1 \mathrm{~mm}$ の石英ガラス, 電極としては長さ $10 \mathrm{~mm}$, 厚さ $0.09 \mathrm{~mm}$ の銅テープを用いている. なお，電極はアクチュエータ近傍への放電を防ぐために石英端から $10 \mathrm{~mm}$ 離し，下側の電極（接地電極）は厚さ $0.06 \mathrm{~mm}$ のポリミイドテープにより被覆されている. 入力波形に関しては正弦波，矩形波，三角波について検討 したが，ここでは本装置において最も大きな誘起速度が得られた正弦波としている.

図 2 は計測装置の概要を示している，プラズマアクチュエータは信号発生器（IWATSU 製：SG-4150)を用いて 印加電圧, 周波数, 波形を設定し, 電力増幅器（松定プレシジョン製 : HEOPT-20B10）によって電圧を増幅し, この高電圧を電極間に印加することによって駆動される. なお，本実験では，アクチュエータへの印加電圧はオ シロスコープ(Tektronix 製：TDS2000B) と高電圧プローブ(Tektronix 製：P6015A）を用いて測定し，電流は接地 電極と接地部との間に抵抗を接続することによって測定している. 消費電力の測定には V-Q リサージュ法を用い $ろ^{(10)(19)}$. V-Q リサージュ法では, 図 3 に示すように横軸に印加電圧 $V$, 縦軸に電荷量 $Q$ をとり, 1 周期における 電圧と電荷によりできる面積を求め, その面積に周波数 $f$ を乗ずることにより消費電力を求めることができる. なお，図中のVe は印加電圧の実効值（rms 值)を示している.

図 4 に誘起速度の測定方法を示寸. 誘起流に関しては, 静止大気中で絶縁性の高いポリミイドの管（古河電工 製 : 外径 $0.72 \mathrm{~mm}$ ，内径 $0.6 \mathrm{~mm}$ ）を用いて製作したピトー管を誘電体先端から $5 \mathrm{~mm}$ 下流の位置に誘電体と平行に 設置し，垂直方向（ $y$ 方向）に移動して速度分布を測定する．また，誘電体表面より $0.6 \mathrm{~mm}$ 上方位置 $(y=0.6 \mathrm{~mm})$ においてピトー管をスパン方向に移動し, 誘起流の二次性について調査寸る.

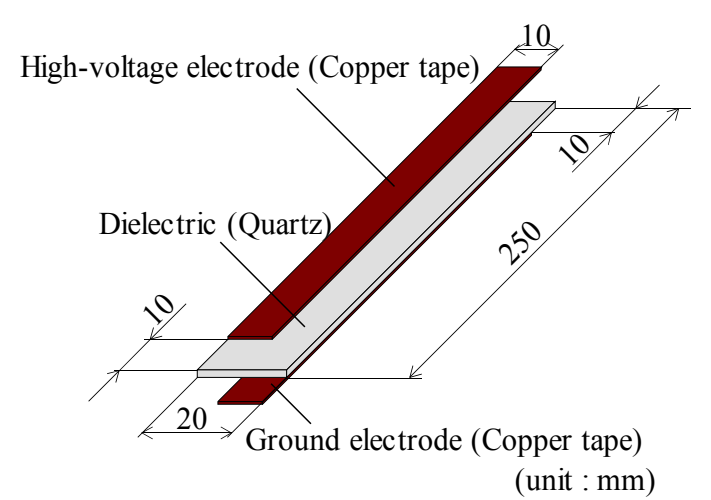

Fig.1 Schematic view of dielectric barrier discharge device

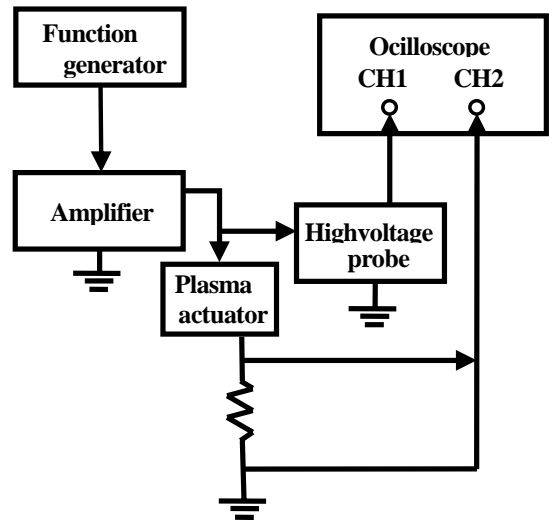

Fig.2 Schematic diagram of instrument system 


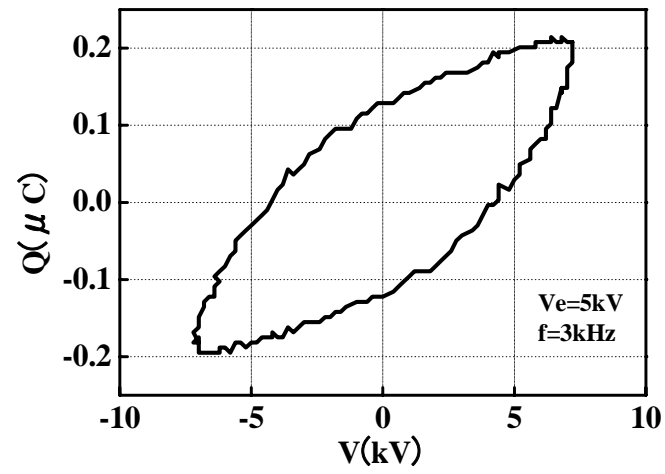

Fig.3 Typical voltage-charge V-Q characteristics

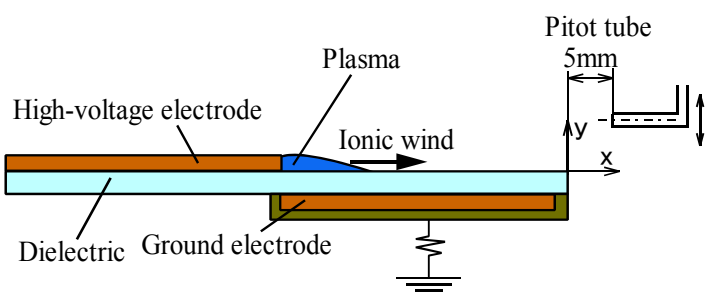

Fig.4 Experimental setup for induced flow velocity

図 5 に本研究で制御対象とする後向きステップ流れの概要とプラズマアクチュエータの設置位置を示す.アク チュエータはステップ角部に設置される. 流路はアクリル板からなりステップ上流の流路高さは $6 \mathrm{~mm}$, ステップ 高さ $H$ も同じく $6 \mathrm{~mm}$ であり，流路拡大比は 2.0 である. 座標はステップからの流れ方向距離を $X$, ステップ下端 からの垂直方向距離を $Y$ とする. なお, 流路入口からステップ部までの長さは $3000 \mathrm{~mm}$, ステップ後方の長さは 1000mm であり, ステップに至る流れは十分に発達している. また, 流路幅は $250 \mathrm{~mm}$ となっているためにステッ プ高さに比較して流路幅は十分大きく, 流れ場は二次元とみなすことができる. 実験は式(1)で定義される Re を 860～3240の範囲で変化させて行われる.

$$
R e=U_{b} H / v \quad\left(U_{b}: \text { ステップ上流での断面平均速度, } v \text { : 動粘度 }\right)
$$

壁面静圧は流路のスパン方向中央位置に直径 $0.5 \mathrm{~mm}$ の静圧孔を流路下側壁面（ステップ側壁面），流路上側壁 面（ステップと対向する壁面）にステップ近傍には 3mm 間隔で設け，微差圧力計(GE Druck 製 : LP9481)を用い て測定する. なお，壁面静圧は式(2)で定義される壁面静圧係数 $C_{p}$ により整理している.

$$
C_{p}=\frac{p-p_{0}}{\rho U_{b}^{2} / 2}
$$

ここで， $p$ は壁面静圧， $p_{0}$ は基準静圧であり $X=-400 \mathrm{~mm}$ の位置における壁面静圧， $\rho$ は密度である．なお，X= $-1100 ，-700 ， 60 ， 700 \mathrm{~mm}$ の位置にはスパン方向の左右 $50 \mathrm{~mm}$ 離れた位置に静圧孔を配置し，壁面静圧分布に 良好な二次元性が確保されていることを確認している.

流路拡大部における圧力損失係数 $\zeta$ は, 損失がないとして求められる圧力回復と, 図 6 に示すように実験によ

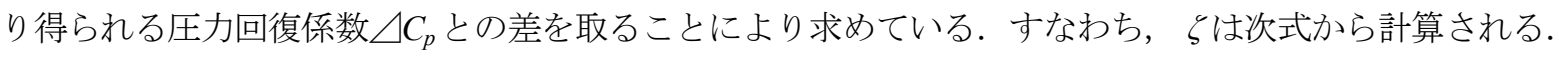

$$
\zeta=\frac{\Delta p_{l}}{\rho U_{b}^{2} / 2}=\left[1-\left(\frac{H}{2 H}\right)^{2}\right]-\Delta C_{p}
$$

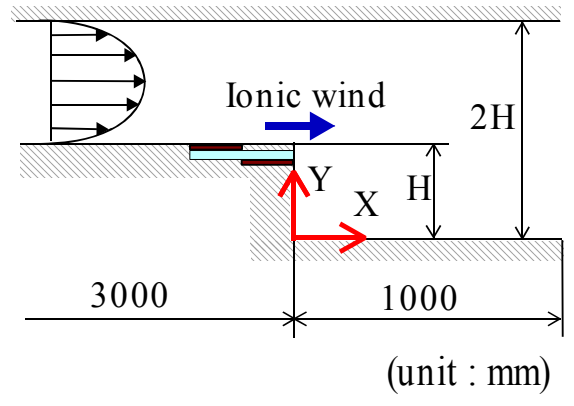

Fig.5 Schematic diagram of test section

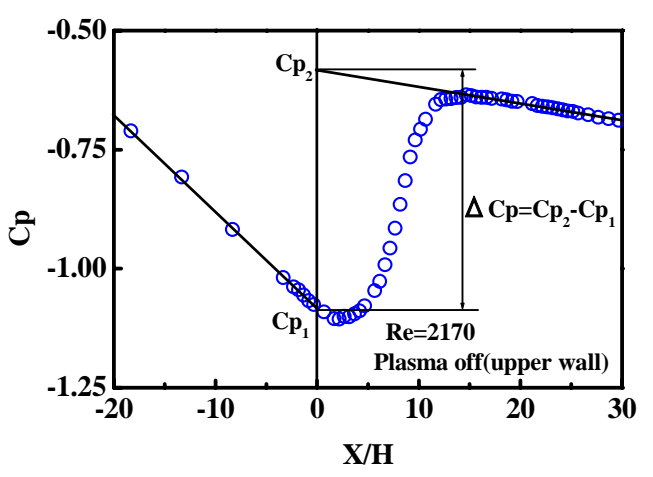

Fig.6 Evaluation method of pressure loss coefficient 
ここで， $\Delta p_{l}$ は拡大部での圧力損失を示している．また，式(3)における右辺の第 1 項は損失がない場合の圧力回 復を，第 2 項は実験的に得られる圧力回復を示している.

ステップ近傍の速度場の計測にはPIV（TSI 社製）システムを用いる．PIVによる測定にあたっては，光源とし て 120mJ/Pulse の出力を持つダブルパルス Nd：YAG レーザ（New Wave 製：DPIV一N120）を使用し，流れに混 入するトレーサ粒子は，煙発生装置 (KANOMAX 製：MODEL 8304）により生成する. 可視化画像は瞬時画像を 1000 フレーム取得し, FFT 相互相関法によって解析する. なお，本研究で用いた PIV の計測手法の詳細は既報(20) に述べられている.

\section{3. 実験結果および考察}

\section{$3 \cdot 1$ プラズマアクチュエータの特性}

図 7 にプラズマアクチュエータの電極に交流電圧を印加した際の電圧と電流の波形の一例を示寸．電圧は入力 した波形(正弦波)と同一の波形を示しているが，電流は従来の結果 ${ }^{(21)}$ (22) と同様に電圧波形から 45 位相がずれた 正弦波とバリア放電によるパルス状の放電電流が周期的に発生していることが確認できる.

図 8 に実効電圧 $V e$ を $5,6,7 \mathrm{kV}$ ，周波数 $f$ を $1,2 \mathrm{kHz}$ と変化させ，誘電体の先端から $5 \mathrm{~mm}$ 下流位置において 測定された誘起流の速度分布を示寸．実効電圧および周波数が高くなるにつれて誘起流速は速くなる．しかしな がら，誘起速度が最も大きくなる位置は，実効電圧，周波数の相違にかかわらず誘電体表面よりわずかに上側 $(y=0.6 \mathrm{~mm})$ であって, この位置には変化が見られない. そこで, $y=0.6 \mathrm{~mm}$ において得られる速度を最大誘起速度 $U_{\max }$ として， $U_{\max }$ を周波数に対して整理した結果を図 9 に示す.Veは $4,5,6 \mathrm{kV}$ と 3 種類変化させているが，い ずれの実効電圧に対しても最大誘起速度は周波数のほぼ 0.5 乗に比例して増加している. 図 10 にはピト一管の垂 直方向位置は $y=0.6 \mathrm{~mm}$ に固定し, 誘電体のスパン方向の中心位置を $z=0$ として, ピトー管をスパン方向に移動し て測定された速度分布を示す．本測定範囲 $(-100 \mathrm{~mm} \leqq z \leqq 100 \mathrm{~mm})$ では，誘起流の二次元性は良好となっている ことが確認できる.

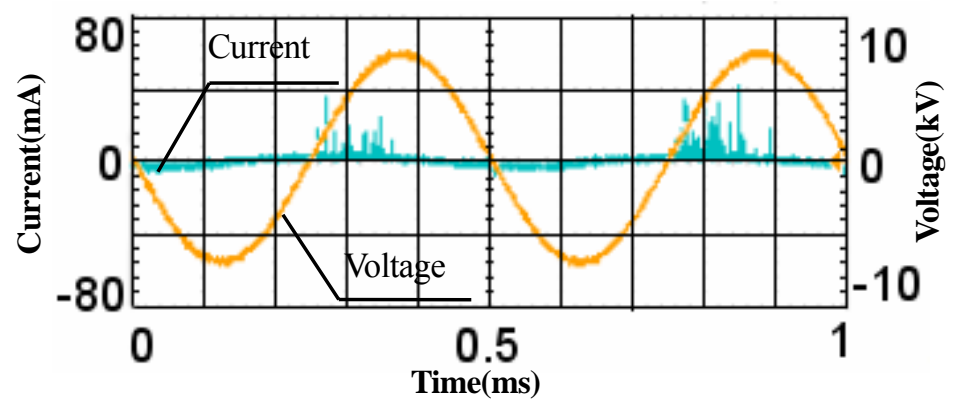

Fig.7 Typical discharge current and voltage waveforms versus time

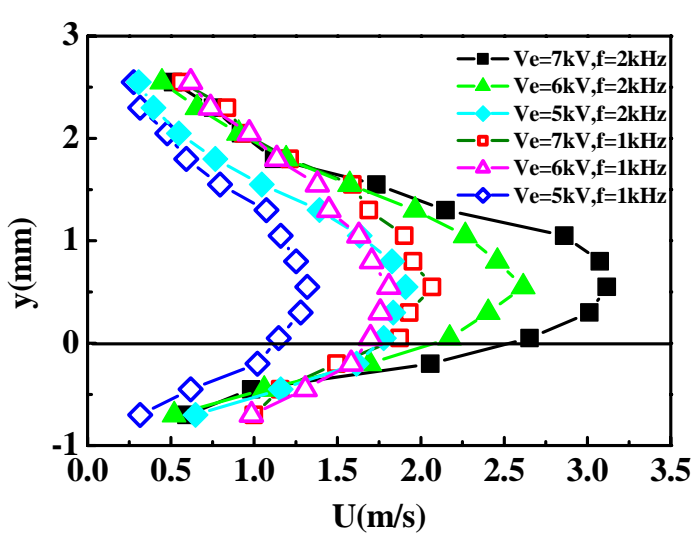

Fig.8 Induced velocity profile

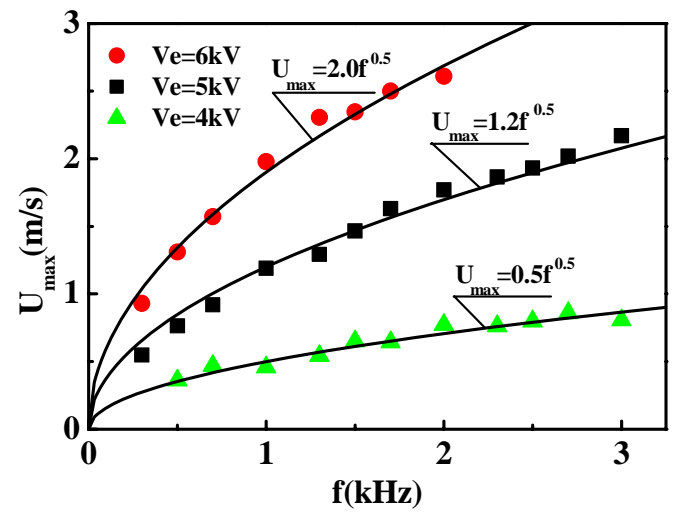

Fig.9 Maximum induced velocity 
図 11 に V-Q リサージュ法を用いて得られた電極幅 $1 \mathrm{~m}$ あたりの消費電力 $P$ の測定結果を示す.この測定では, 実効電圧が $V e=4,5,6 \mathrm{kV}$ のもとで, 周波数を $f=0.3 \mathrm{kHz} \sim 3 \mathrm{kHz}$ の範囲で変化させている. 消費電力は実効電圧が 高くなるにつれて増加する. また，実効電圧が一定の場合には周波数にほぼ比例して増加する．この傾向は Forte ら ${ }^{(23)}$ によって得られた結果と一致する. なお, 本実験で使用している電極幅は $230 \mathrm{~mm}$ であるため, 実際の消費 電力は $V e=6 \mathrm{kV}, f=2 \mathrm{kHz}$ の条件では $10.5 \mathrm{~W}$ となる.

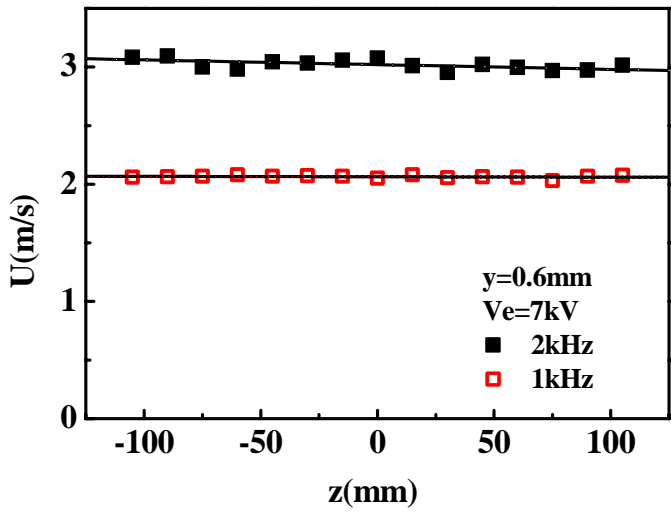

Fig.10 Induced velocity profile

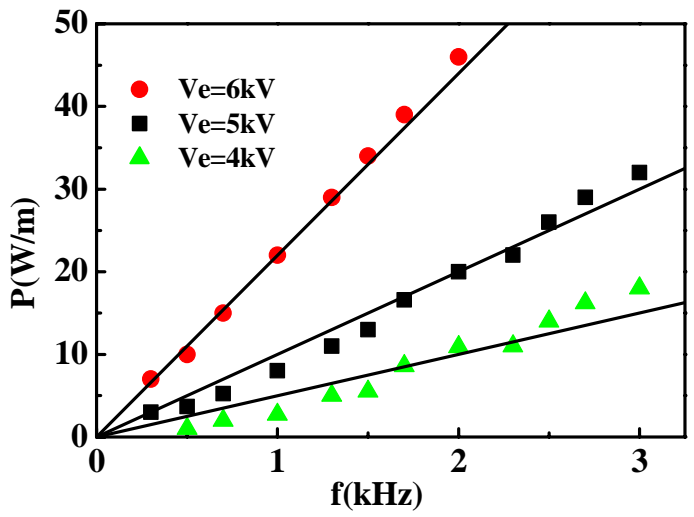

Fig.11 Electrical power consumption

\section{$3 \cdot 2$ 後向きステップ流れの圧力特性}

図 12 にアクチュエータを駆動していない場合とアクチュエータを $V e=6 \mathrm{kV}, f=2 \mathrm{kHz}$ の条件で駆動した場合にお いて得られた流路下側（ステップ側壁面），および流路上側（ステップと対向する壁面）の壁面静圧係数 $C_{p}$ の流 れ方向分布を $R e=1080 ， 1520 ， 2170$ の場合を代表例として示す．なお，ステップ上流における流路の水力直径を 代表寸法としたレイノルズ数は, $R e=1080$ では $2110, R e=1520$ では $2960, R e=2170$ では 4230 となる. したがっ て, ステップに至る流れは $R e=1080$ では層流域, $R e=1520$ では遷移域, $R e=2170$ では乱流域にあるとみなすこと ができる.

$R e=1080$ の結果では, アクチュエータを駆動していない場合の下側壁面での $C_{p}$ は $X / H=12$ 程度まで一定值に近 く, その下流で急激な増加が認められる. 上側壁面では, 下側壁面に比較して圧力増加の現れる位置が上流側に 移動するが, $X / H=15$ 付近からは下側壁面での $C_{p}$ 分布とほぼ一致する. 一方, アクチュエータを駆動した場合に は, $C_{p}$ 分布に増加が現れ始める位置がステップ側に移動する. また, 下側壁面と上側壁面とで $C_{p}$ 分布に顕著な 差が見られ，下側壁面の $C_{p}$ 分布には $X / H=6$ 付近に極大值が， $X / H=8$ 付近に極小值が現れている. アクチュエー タを駆動することによりステップ近傍の流れが大きく変化していることが示唆される. また， ステップ後方の $C_{p}$ が直線的に降下している領域での $C_{p}$ の值は, アクチュエータを駆動していない場合に比較して大きくなっており， アクチュエータの駆動により高い圧力回復が得られていることがわかる．Re=1520 の結果では, アクチュエータ を駆動していない場合の下側壁面で $C_{p}$ が急激に増加を開始する位置は $X / H=7$ 付近にあるが，アクチュエータを 駆動することにより $X / H=4$ 程度まで上流側に移動し，かつ $R e=1080$ ほど顕著ではものの $C_{p}$ 分布にわずかな極大 と極小の存在を認めることができる. $R e=2170$ の結果では, アクチュエータを駆動しても下側壁面と上側壁面と

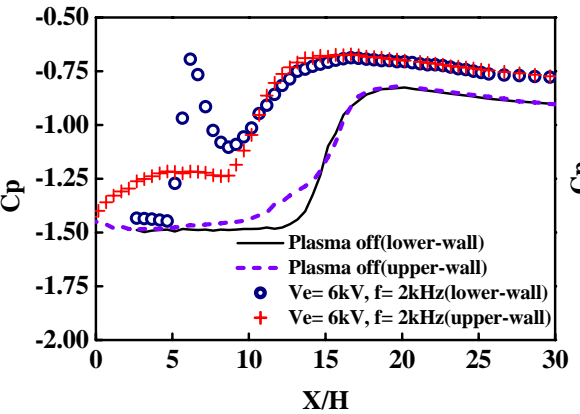

(a) $\mathrm{Re}=1080$

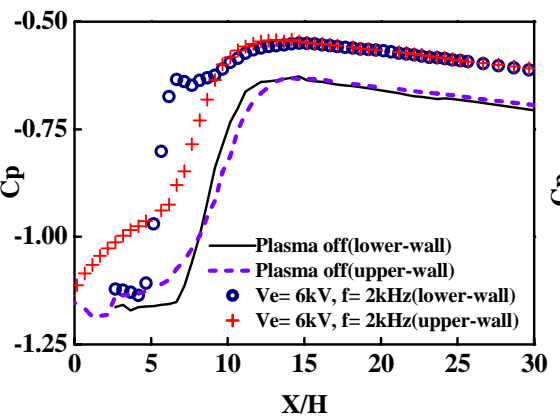

(b) $\mathrm{Re}=1520$

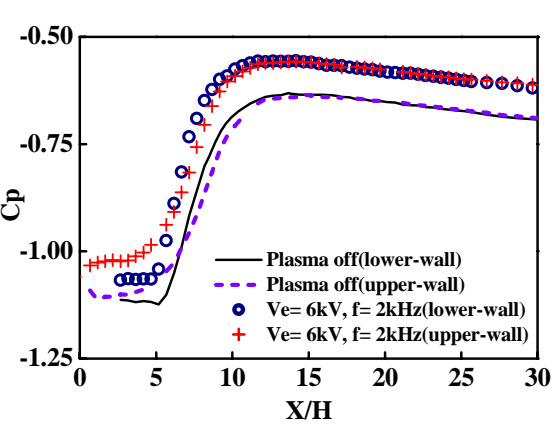

(c) $\mathrm{Re}=2170$

Fig.12 Wall static pressure coefficient 
の分布形状の相違はあまり見られず, $X / H=7$ 付近から流路下側と流路上側の $C_{p}$ 分布は一致する. 一般的傾向とし て, Re が高くなるにつれて下側壁面と上側壁面とで測定された $C_{p}$ 分布の差は小さくなり，かつアクチュエータ 駆動の有無による分布形状の変化も小さくなる．しかしながら，いずれの Re においてもステップから離れた領 域での $C_{p}$ 值は，アクチュエータを駆動していない場合に比較して高くなっており，このアクチュエータが流路の 拡大に伴う圧力損失の低減に有効となることを示している.

図 13 にアクチュエータを駆動していない場合と駆動した場合の流路拡大部における圧力損失係数 $\zeta$ を $R$ に対 してプロットした結果を示す.アアチュエータの駆動の有無にかかわらず Re が増加するにつれて圧力損失係数 は増加するが，その増加傾向は Reの低い領域では急激で，高い領域では緩やかとなる． $V e=5 \mathrm{kV}, f=2 \mathrm{kHz}$ の条件 では，低 $R e$ 領域でわずかな圧力損失係数の減少しか認められない．しかしながら， $V e=6 \mathrm{kV}, f=2 \mathrm{kHz}$ の条件では 明らかな圧力損失係数の減少を確認できる. 図 14 には, 圧力損失の低減効果を定量的に評価するため, 式(4)で 定義される圧力損失係数の低減率 $D R$ をReに対してプロットした結果を示す.

$$
D R=\frac{\zeta_{\text {off }}-\zeta_{o n}}{\zeta_{\text {off }}} \times 100 \quad\left(\zeta_{\text {off }}: \text { アクチュエータ駆動なし }, \zeta_{o n}: \text { アクチュエータ駆動あり }\right)
$$

図 14 より Reの低い層流域において圧力損失係数の低減率は大きくなり, 流路の拡大に伴う圧力損失を大幅に低 減できることがわかる. 特に $V e=6 \mathrm{kV}, f=2 \mathrm{kHz}$ の条件では, 最大で $31 \%$ の圧力損失の低減が可能となる. また, 本実験で最も $R e$ が大きい $R e=3240$ においても $9 \%$ の低減が得られる. 本研究で用いたアクチュエータは，ステ ップに至る流れが乱流の場合であっても圧力損失の低減に有効となる.

そこで，次節においてアクチュエータを $V e=6 \mathrm{kV}, f=2 \mathrm{kHz}$ の条件のもとで駆動した場合の速度場の測定結果に ついて述べる.

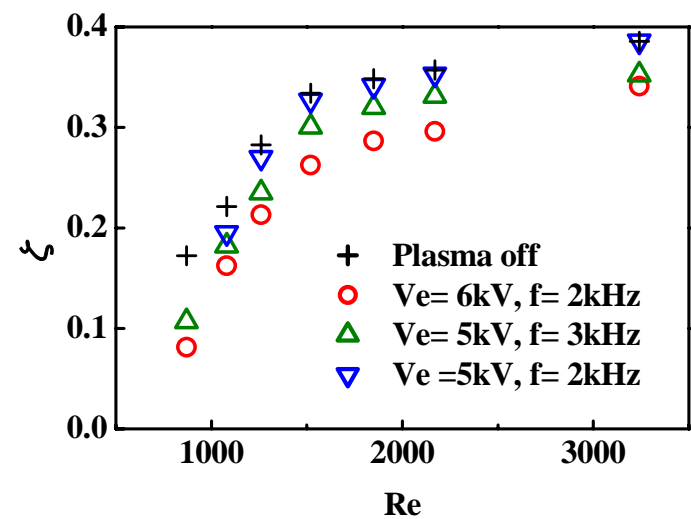

Fig.13 Pressure loss coefficient

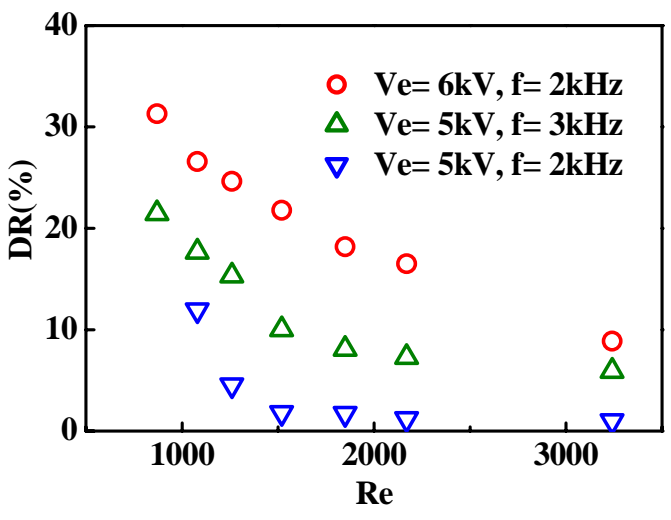

Fig.14 Pressure loss reduction rate

\section{$3 \cdot 3$ 後向きステップ流れの流動特性}

図 15 に $R e=1080$ のもとで測定された流れ方向速度 $U$ と垂直方向速度 $V$ を $U_{b}$ で無次元化して等值線として示す. なお，(a)は流れ方向速度，(b)は垂直方向速度の測定結果である. アクチュエータを駆動していない場合の再付着 点位置は $X / H=13$ 付近にあり，その位置より上流側には広い範囲にわたる再循環領域が存在している，一方，ア クチュエータを駆動した場合には，流路の上壁面側に $X / H=6$ 付近を中心とした逆流域があるが，下壁面側にはス テップ角部付近からステップ壁面に向から高速な下向きの流れが存在している. これは，アクチュエータの駆動 によって発生した誘起流によりコアンダ効果が生じたものと考えられる.この効果により, 再付着点位置は $X / H=3$ 程度まで上流側に移動し，ステップ側の再循環領域は非常に狭い範囲に縮小される．再循環領域の縮小は，後向 きステップにおいて発生する急拡大損失の低減に寄与しているものと考えられる. また, 図 12 に示した流路下側 壁面の $C_{p}$ 分布には, $X / H=6$ 付近に極大值が, $X / H=8$ 付近に極小值が見られたが，極大值はステップ角部付近から の高速流体が下側壁面に到達する位置付近に，極小值は正の垂直方向速度が大きく，流路のステップ壁面側から 中心側に向かう流体運動が顕著となる位置付近に現れている.

図 16 には $R e=1520$ の条件で得られた測定結果を示す。この条件では, アクチュエータを駆動していない場合 の再付着点位置は $X / H=8$ 付近にあるが, アクチュエータを駆動した場合の再付着点位置は $X / H=4$ 付近まで減少す 
る.また，Re=1080 で観察されたほど顕著ではないが，ステップ上流の高速流が湾曲しながら流路下壁面側に向 かって流れている様子を見ることができる．また，ステップ後方には $X / H=2, \quad Y / H=0.3$ 付近を中心とする流路の 中央に向かう流れが存在する.
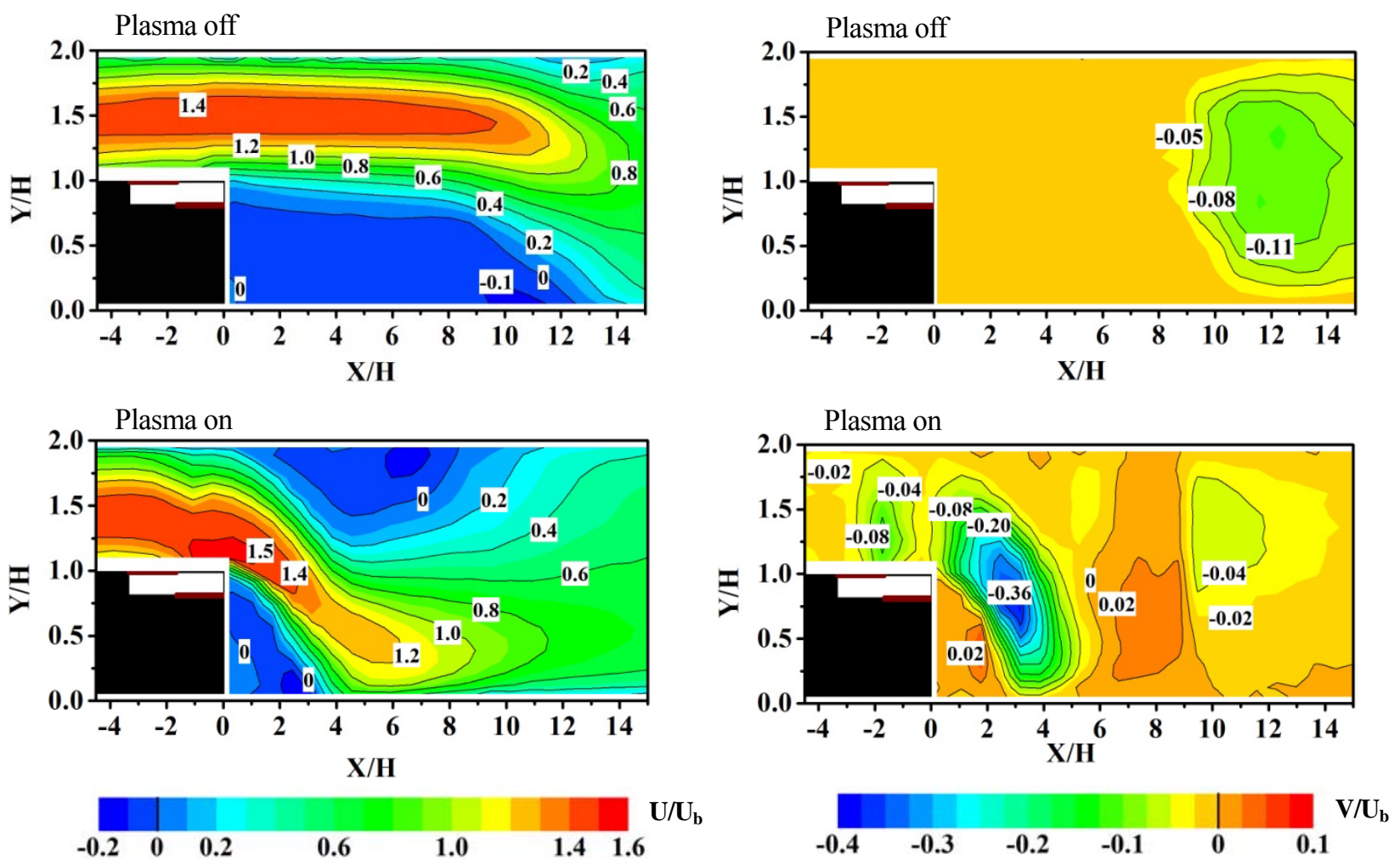

(a) streamwise velocity

(b) wall-normal velocity

Fig. 15 Contours of streamwise and wall-normal velocities for $R e=1080$
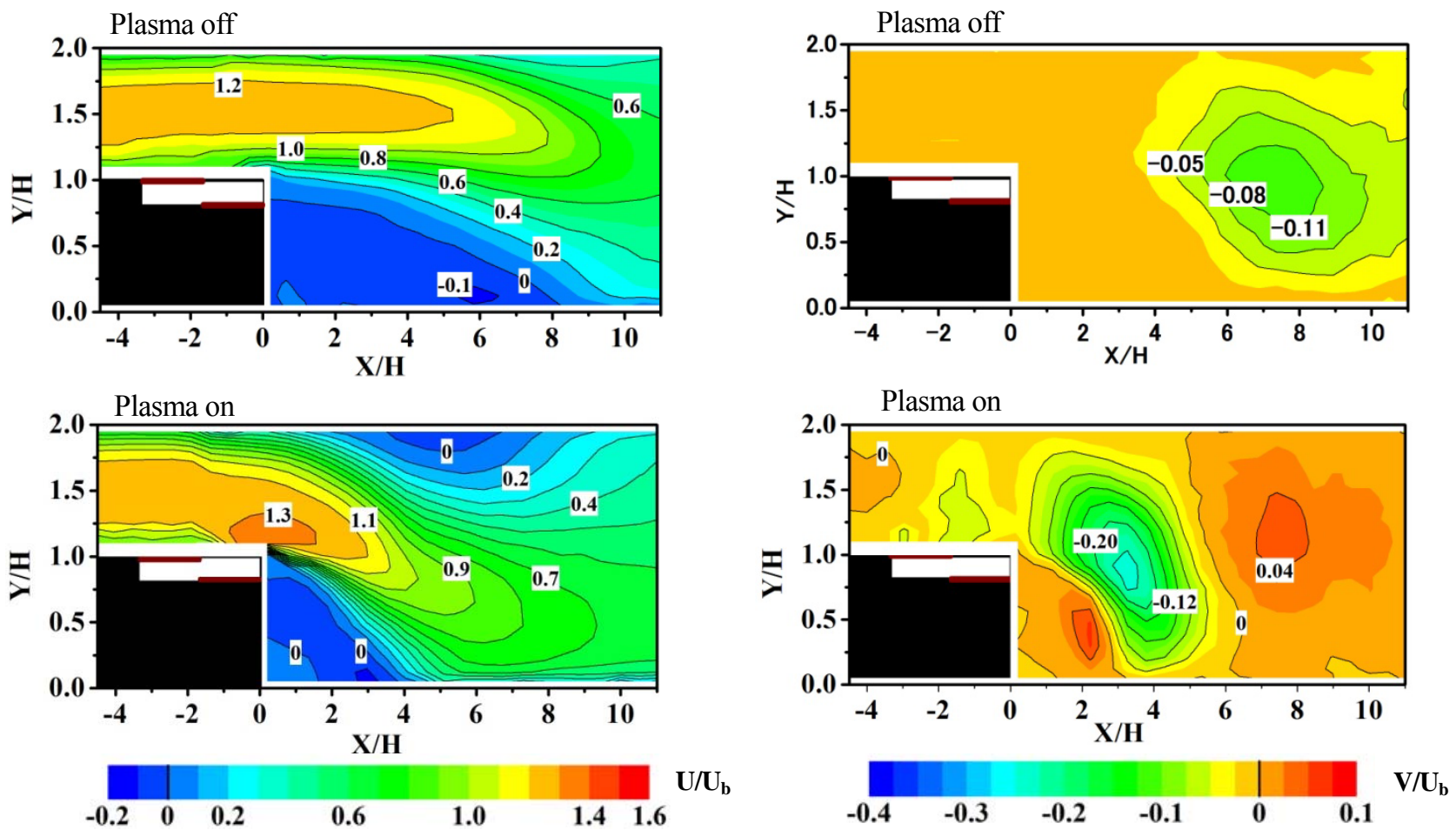

(a) streamwise velocity

(b) wall-normal velocity

Fig.16 Contours of streamwise and wall-normal velocities for $R e=1520$ 
図 17 に示した $R e=2170$ の測定結果では，ステップに至る流れが乱流となるためにステップ上流部での速度分 布は平坦なものとなり, $U_{b}$ で無次元化したステップ上流の流路中央部での等值線の值は他の $R e$ に比較して小さ くなる. アクチュエータを駆動していない場合の再付着点位置は $X / H=7$ 付近であり, アクチュエータを駆動した 場合の再付着点位置は $X / H=5.5$ 程度である. $R e=1080,1520$ に比較するとその効果は小さいが，流れが乱流にな った場合においてもこのアクチュエータが再循環領域の縮小に寄与していることがわかる.

図 18 に代表的な位置における流れ方向速度 $U$,ならびに垂直方向速度 $V$ を $U_{b}$ で無次元化した速度分布を示す。 なお，図中の実線はアクチュエータを駆動していない場合の結果である. Re=1080 における流れ方向の速度分布 からは, アクチュエータの駆動より電極付近の壁面近傍の流れが加速されている様子を見ることができる. $X / H=1$ より下流の位置では，Uの分布に最大值が現れる位置がステップ壁面側に移動している．垂直方向の速度に関し ては, $X / H=-2$ の位置においてアクチュエータの駆動による吸込み流の存在 ${ }^{(24)}$ にって負の值となる. ステップ の下流では下側壁面に向から流れが見られ, 特に $X / H=2,3$ の位置には非常に強い下向きの流れが認められる. $R e=1520$ における流れ方向の速度分布からは, アクチュエータを駆動させることにより, ステップ近傍の $Y / H=1$ 付近での流れ方向速度の増速が見られる. 垂直方向速度に関しては， $X / H=4$ での負の值が大きいが，この位置は はく離した流れが再付着する位置にほぼ対応している. また, アクチュエータを駆動していない場合には, $X / H=9$ の位置における負の值が最も大きいが，アクチュエータを駆動した場合にはこの位置での垂直方向速度成分はほ ぼ零となる．Re=2170 の流れ方向の速度分布においては，ステップ上流ではアクチュエータを駆動させても， $R e=1080,1520$ で見られたほどの変化は確認できない，しかし，ステップ近傍の $X / H=1 ， 2$ の位置では，はく離 せん断層が流路下側へ移動している様子が確認できる. なお，垂直方向の速度分布に関しては，ステップ上流で は流れ方向速度の場合と同様にアクチュエータ駆動による変化はほとんど観察されない. また $X / H=2,4$ の位置 で，わずかに負の值が大きくなる程度である. また， $R e=1080,1520$ の結果に比較して垂直方向速度がかなり小 さく, $X / H=8$ の位置においては, アクチュエータの駆動の有無による差はほとんど認められなくなる.
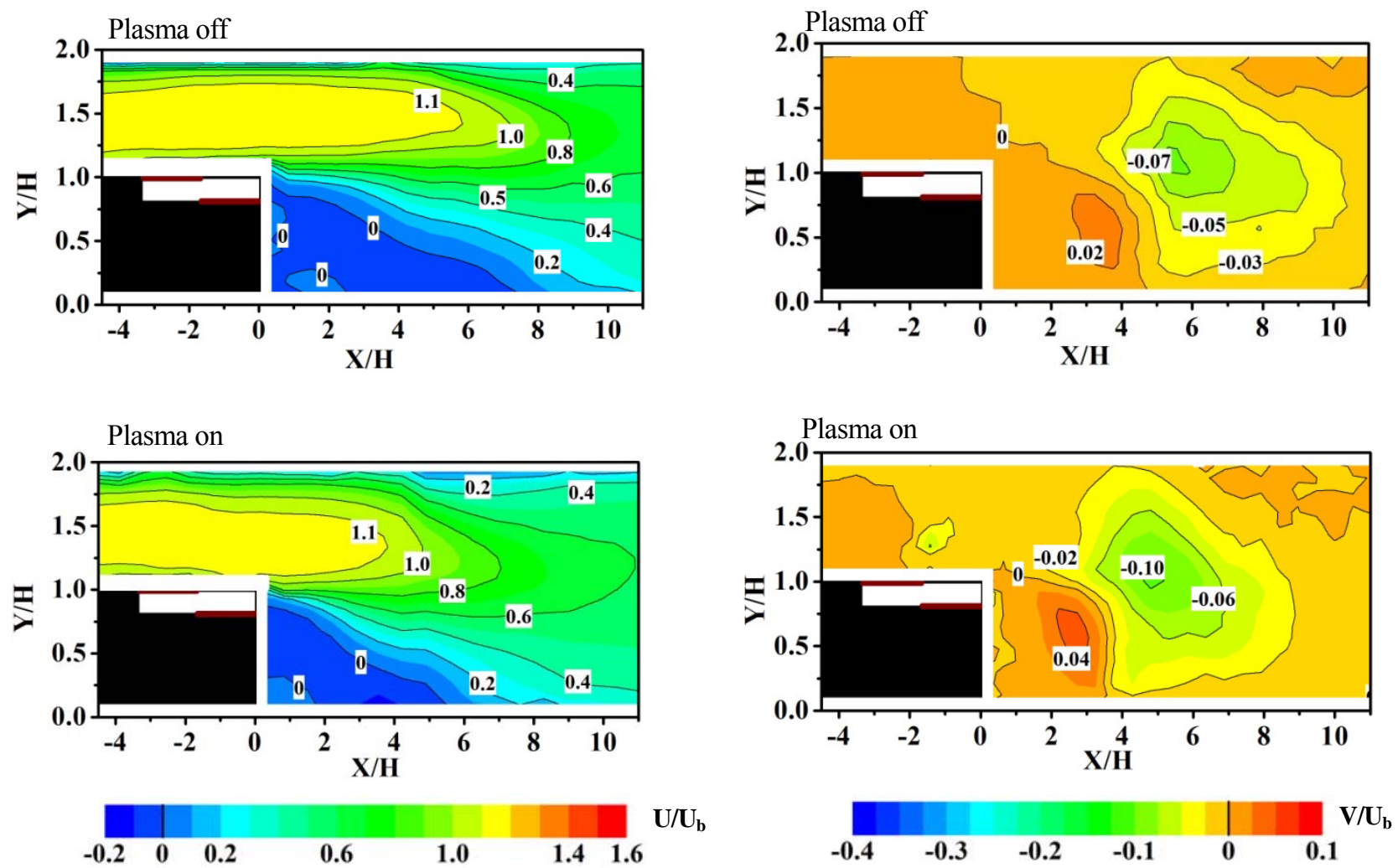

(a) streamwise velocity

(b) wall-normal velocity

Fig. 17 Contours of streamwise and wall-normal velocities for $R e=2170$ 
図 19 にステップに至る流れが乱流となっている $R e=2170$ での代表的な位置における流れ方向の乱れの実効值 $u_{r m s}$, ならびに垂直方向の乱れの実効值 $v_{r m s}$ を $U_{b}$ で無次元化した乱流強度分布を示寸. なお, 図中の実線はアク チュエータを駆動していない場合の結果である. (a)に示した流れ方向乱流強度分布からは, アクチュエータの駆 動により $X / H=0,1 ， 4$ の位置での極大值の現れる位置が流路の下壁面側に移動していることが確認できる.これ は, 速度分布に見られた せん断層の流路下側への移動に対応している. また, 流れ方向, 垂直方向ともに $X / H=1$, 2 の位置におけるステップ側の乱流強度は, アクチュエータを駆動していない場合に比較して大きくなっている. 乱れの増大は，流路中心側の大きな運動量をもつ流体と再循環領域の流体の混合を促進することになり ${ }^{(25)}$, この ことがアクチュエータの駆動により再付着点位置が上流側に移動することに関係していると考えられる.
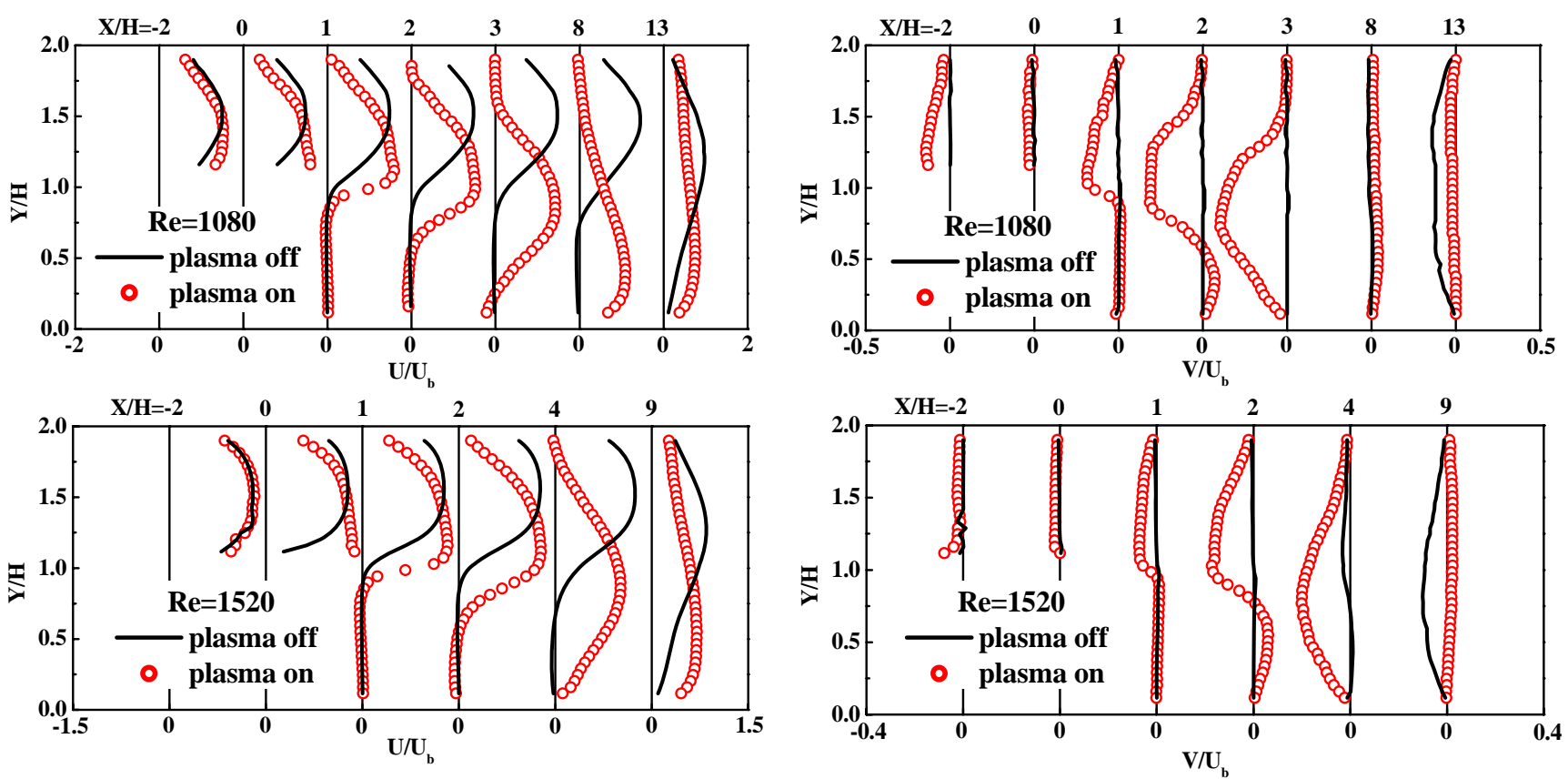

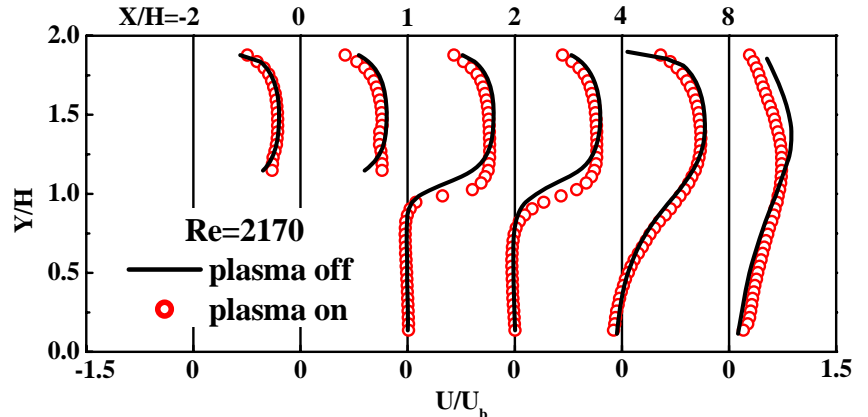

(a) streamwise velocity

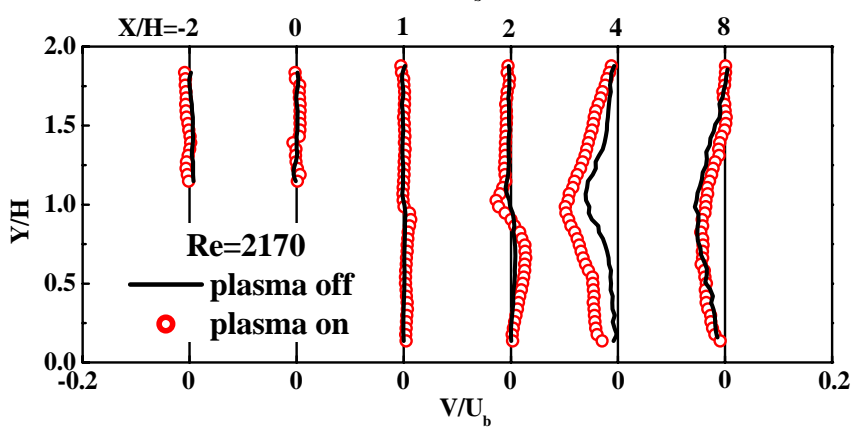

(b) wall-normal velocity

Fig.18 Velocity profiles

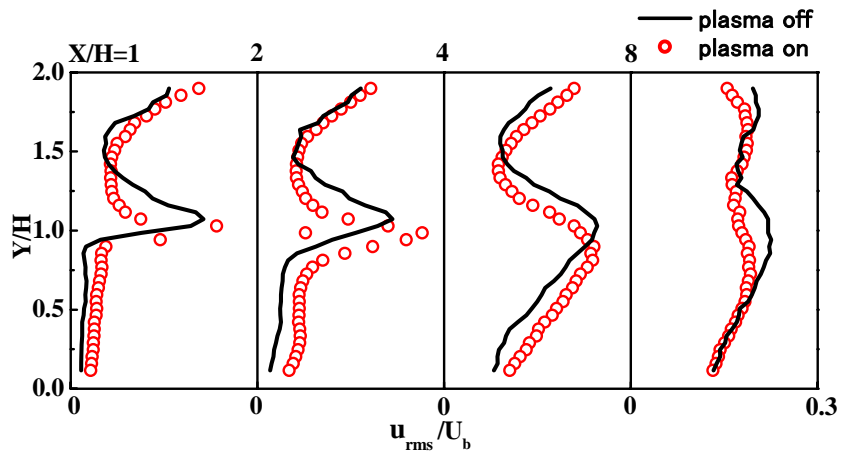

(a) streamwise turbulence intensity

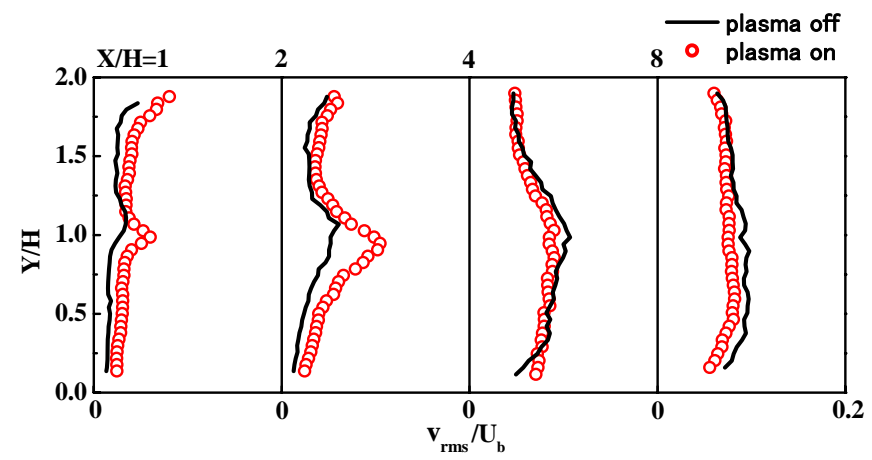

(b) wall-normal turbulence intensity

Fig.19 Turbulence intensity profiles for $R e=2170$ 


\section{4. 結言}

本論文では最初に，使用したプラズマアクチュエータの基本特性を明らかにした後，このアクチュエータを後 向きステップ流れに適用した場合の有効性について検証した.ついで, 代表的な Reについては, PIVを使用して 流動特性を調查した．本研究によって得られた主要な結論を要約して以下に示す.

（1）誘起速度に最大值が現れる位置は, アクチュエータの駆動条件の相違にかかわらず誘電体表面よりわずかに

上側となる.また，いずれの実効電圧においても最大誘起速度は周波数のほぼ 0.5 乗に比例して増加し，消費 電力は周波数にほぼ比例して増加する.

（2）アクチュエータの駆動により，ステップに至る流れが層流，乱流の場合ともに流路の拡大にともなう圧力損 失を低減できる.Reの低い領域では, 最大で $31 \%$ の圧力損失の低減効果が得られる.

（3）アクチュエータの駆動により再付着長さを短くできる. 特に, 層流域の流れに対しては, ステップ角部付近 からの高速流体が壁面方向に向かう流れが強くなり, 再付着点位置はステップ側に移動する.

（4）アクチュエータを乱流域の流れに適用した場合には, ステップ直後におけるステップ側の乱流強度が増加す る.このことは，再付着長さの縮小に寄与する.

\section{文献}

(1) Chun, S., Lee, I. and Sung, H. J., "Effect of spanwise-varying local forcing on turbulent separated flow over a backward-facing step flow", Experiments in Fluids, Vol. 26 (1999), pp.437-440.

(2) Yoshioka, S., Obi, S. and Masuda, S., "Organized vortex motion in periodically perturbed turbulent separated flow over a backward-facing step flow", International Journal of Heat and Fluid Flow, Vol. 22 (2001), pp.301-307.

（3）佐野正利，鈴木一平，櫻庭健一郎，“吸込みによる後向きステップを有するチャネル乱流の制御”, 日本機械学会論 文集 B 編, Vol. 74, No. 744 (2008), pp.1762-1769.

(4) 山田俊輔, 本阿弥眞二, 岡本圭太, 新田貴志, 元祐昌廣, 石川仁, ”低レイノルズ数域における後方ステップ流れ の制御に関する研究(安定性解析を利用したSynthetic jetによる再付着流れの制御)”, 日本機械学会論文集 B 編, Vol. 77, No. 775 (2011), pp.680-688.

（5）鈴木 洋，鈴木健二郎，喜多茂雄，中前隆行，”後向きステップ流の熱伝達不領域における伝熱促進（上端角近傍 に円柱を挿入した場合”，日本機械学会論文集 B 編, Vol.57, No.536 (1991), pp.1410-1415.

(6) 親川兼勇, 斉藤武史, 照屋 功, 馬淵幾夫, ”スラットを用いた後向きステップ下流の再付着領域の熱伝達促進”, 日本機械学会論文集 B 編, Vol. 61, No.592 (1995), pp.4426-4431.

(7) 佐野正利, 鈴木一平, ”傾斜した後向きステップを有するチャネル乱流に関する研究”, 日本機械学会論文集 B 編, Vol. 75, No.755 (2009), pp.1395-1401.

(8) Corke, T. C., Enloe, C. L. and Wilkinson, S. P., " Dielectric barrier discharge plasma actuators for flow control", Annual Review of Fluid Mechanics, Vol. 42 (2010), pp.505-529.

（9）梁潟康二，山田俊輔，石川 仁，”プラズマアクチュエータの基礎と研究動向”, ながれ, Vol. 29 (2010), pp.243-250.

(10) Moreau, E., "Airflow control by non-thermal plasma actuators", Journal of Physics D: Applied Physics, Vol. 40 (2007), pp.605-636.

(11) 小方 聡, 射越 悠, 瀬川武彦, ”プラズマアクチュエータによる誘起流制御に関する研究（印加電圧特性が誘起 流方向に及ぼす影響) ”, 日本機械学会論文集 B 編, Vol.77, No.775 (2011), pp.672-679.

(12) 山田俊輔, 柴田浩意, 石川 仁, 瀬川武彦, ”プラズマアクチュエータによる円柱流れの制御に関する研究（第 1 報，後流における時間平均特性）”, 日本機械学会論文集 B 編, Vol. 76, No. 772 (2010), pp.2011-2017.

(13) 長谷部仁美, 中 吉嗣, 深潟康二, ”プラズマアクチュエータを用いた翼端渦抑制の試み”, 日本機械学会論文集 B 編, Vol. 77, No. 775 (2011), pp.659-671.

（14）樋口丈浩, 小河原加久治, 望月信介, ”プラズマシンセティックジェットアクチュエータの平面せん断層における 壁面せん断応力の直接計測”, 日本機械学会論文集 B 編, Vol. 77, No. 777 (2011), pp.1239-1248.

(15) 松田 寿, 田中元史, 五嶋祥平, 大久保辰郎, 跡部 隆, 小林 宙, ”プラズマアクチュエータを用いた後向きス テップ流れの制御に関する実験的研究”, ながれ, Vol. 29 (2010), pp.411-416. 
(16) Roth, J. R. and Dai, X., "Optimization of the aerodynamic plasma actuator as an electrohydrodynamic (EHD) electrical device", AIAA 2006-1203 (2006), pp.1-28.

(17) 佐野正利, 須藤輝美，鈴木 進， ”プラズマアクチュエータによるチャネル流れの抵抗低減”, 日本機械学会講演論 文集, No. 098-3 (2009), pp.63-64.

(18) 遠藤慶亮，須藤輝美，鈴木 進，佐野正利，“プラズマアクチュエータの基本特性とチャネル流れへの応用”,日本機 械学会講演論文集, No.100-3 (2010), pp.38-39.

(19) 日本学術振興会プラズマ材料科学第 153 委員会編, "大気圧プラズマ 基礎と応用", (2009), pp.126-127, オーム社.

(20) 櫻庭健一郎, 遠藤大樹, 佐野正利, “後向きステップを有するチャネル乱流の受動的制御（流動特性）”，日本機械 学会論文集 B 編, Vol. 70, No. 699 (2004), pp.2805-2812.

(21) Moreau, E., Louste, C. and Touchard, G., "Electric wind induced by sliding discharge in air at atmospheric pressure", Journal of Electrostatics, Vol. 66 (2008), pp.107-114.

(22) 伊藤 悟, 大河内翔平, 鈴木雄二, 笠木伸英, ”流体制御に用いるマイクロ・プラズマアクチュエータの変換効率 に関する研究”, 日本機械学会論文集 C 編, Vol. 76, No. 768 (2010), pp.1914-1916.

(23) Forte, M., Jolibois, J., Pons, J., Moreau, E., Touchard, G. and Cazalens, M., “Optimization of a dielectric barrier discharge actuator by stationary and non-stationary measurements of the induced flow velocity : application to airflow control", Experimental Fluids, Vol. 43 (2007), pp. 917-928.

(24) 大河内翔平，笠木伸英，鈴木雄二，”マイクロ・プラズマアクチュエータの特性”, ながれ, Vol. 29 (2010), pp.271-276.

（25）瓜田 明，田中周治，”周期変動噴流を用いた後方ステップ流れの能動的制御（第 1 報，噴流条件の影響とはく離 流れ場の構造）”，日本機械学会論文集 B 編, Vol. 75, No. 749 (2009), pp.19-27. 